\title{
EFFECTS OF DIFFERENT WATER CONDITIONS ON RICE GROWTH AT THE SEEDLING STAGE ${ }^{1}$
}

\author{
JUN ZHANG ${ }^{2}$, YANYAN $\mathrm{LI}^{2}$, HAOYU ZAHNG ${ }^{2}$, PENG DONG ${ }^{2}, \mathrm{CHANGZHOU} \mathrm{WEI}^{2 *}$
}

\begin{abstract}
Water scarcity has led to the adoption of water-saving irrigation technology around the world. Drip-irrigation has been used for rice (Oryza sativa L.) cultivation in Xinjiang, China. Researchers reported $12.0 \mathrm{t} / \mathrm{ha}$ yield; however, drip-irrigated rice produces around 6-8 t/ha in practice, and it is clear that water deficiency explains this gap. Therefore, the objective of this experiment was to compare the growth, photosynthetic characteristics, and antioxidant activity of rice grown in nutrient solutions with water potentials of $0.00,-0.02,-0.05$, and $-0.09 \mathrm{MPa}[0,2.5,5.0$, and $7.5 \%$ polyethylene glycol (PEG), respectively], to determine the optimal water conditions for drip-irrigated rice. There was no significant difference between the $0,2.5$, and 5.0\% PEG treatments for relative growth rate and relative water content after 10 and 20 days. However, 2.5 and 5.0\% PEG treatments substantially affected the photosynthetic capacity and antioxidant enzyme activity after 10 and 20 days. Treatment with 7.5\% PEG inhibited shoot growth. There was a significant reduction in antioxidant enzyme activity. Water-saving rice cultivation, such as drip-irrigated rice, suffered mild drought stress at -0.02 to $-0.05 \mathrm{Mpa}$, but this did not inhibit growth. The amount of irrigation should be increased to obtain higher rice yields under drip-irrigation conditions.
\end{abstract}

Keywords: Aerobic condition. Enzyme activity. Photosynthetic capacity.

\section{EFEITOS DE DIFERENTES CONDIÇÕES DE ÁGUA SOBRE O CRESCIMENTO DE ARROZ NA FASE DE MUDAS}

\begin{abstract}
RESUMO - A escassez de água levou à adoção de tecnologia de irrigação que economiza água em todo o mundo. A irrigação por gotejamento tem sido usada para o cultivo de arroz em Xinjiang, China. Pesquisadores relataram 12,0 t/ha de rendimento; no entanto, o arroz irrigado por gotejamento produz cerca de 6-8 t/ha na prática, e está claro que a deficiência de água explica essa lacuna. Portanto, o objetivo deste experimento foi comparar o crescimento, as características fotossintéticas e a atividade antioxidante do arroz cultivado em solução nutritiva com potencial hídrico de $0,00,-0,02,-0,05$ e - $-0,09 \mathrm{MPa}[0,2,5,5,0$ e 7,5 \% polietilenoglicol (PEG), respectivamente], para determinar as condições ótimas da água para o arroz irrigado por gotejamento. Não houve diferença significativa entre os tratamentos $0,2,5$ e 5,0\% de PEG para a taxa de crescimento relativo e o conteúdo relativo de água após 10 e 20 dias. No entanto, os tratamentos de 2,5 e 5,0\% de PEG afetaram substancialmente a capacidade fotossintética e a atividade das enzimas antioxidantes após 10 e 20 dias. O tratamento com 7,5\% de PEG inibiu o crescimento das brotações. Houve uma redução significativa na atividade das enzimas antioxidantes. $\mathrm{O}$ cultivo de arroz que economiza água, como o arroz irrigado por gotejamento, sofreu um leve estresse hídrico de -0,02 a -0,05 Mpa, mas isso não inibiu o crescimento. A quantidade de irrigação deve ser aumentada para obter maiores rendimentos de arroz sob condições de irrigação por gotejamento.
\end{abstract}

Palavras-chave: Condição aeróbica. Atividade enzimática. Capacidade fotossintética.

\footnotetext{
${ }^{*}$ Corresponding author

${ }^{1}$ Received for publication in 02/07/2018; accepted in 11/19/2018.

${ }^{2}$ Key Lab of Oasis Ecology Agriculture of Xinjiang Production and Construction Group, Universidade de box de Shi, Shihezi, Xinjiang, China; zhangjun0993@sina.com - ORCID: 0000-0003-4929-6474, 1yy9085@126.com - ORCID: 0000-0003-4414-2847, 849592583@qq.com - ORCID: 0000-0001-9052-3806, dongpeng125@163.com - ORCID: 0000-0002-4505-5713, changzhouwei@126.com - ORCID:0000-0003-1677-0678.
} 


\section{INTRODUCTION}

Rice (Oryza sativa L.), a staple food for many people in Asia, is generally grown under flooded conditions. Irrigation water is becoming increasingly scarce (NELSON; WASSMANN; SANDER, 2015). It is estimated that by 2025 , fresh water will be less available and irrigated rice production will suffer from some degree of water scarcity (LAMPAYAN et al., 2015). Reduced water availability for agriculture threatens the productivity of irrigated ecosystems (WANG et al., 2012). Therefore, new strategies are sought to save water and sustain rice production.

Water scarcity has already led to the adoption of water-saving technology for rice production. Upland rice has been cultivated for decades in India, Southeast Asia, and South America. Recently, farmers have attempted to grow rice with drip irrigation and plastic film mulch (DI-PFM) in the Xinjiang Uyghur Autonomous Region of northwest China (HE et al., 2014). In the DI-PFM system, small amounts of irrigation water are frequently applied to the soil to maintain the soil moisture content at $>90 \%$ of the field capacity, but not flooded. Rice yields as high as $12.0 \mathrm{t} /$ ha have been reported when soil water content is maintained at $>90 \%$ of field water capacity (GUO; CHEN, 2012; ZHU et al., 2013), which reduces water use by about $60 \%$ (HE et al., 2014). However, drip-irrigation rice growers have reported that rice is more vulnerable to stress than flooding rice. For example, drip-irrigated rice is easily affected by salinity (BAI et al., 2017), $\mathrm{HCO}_{3}{ }^{-}$content (ZHANG et al., 2015), and chlorosis in the seedling stage. Normally, drip-irrigated rice produces yields of $6-8 \mathrm{t} / \mathrm{ha}$, which is much lower than the performance of flooding rice .Drip-irrigated rice is more vulnerable than flooded rice is due to water stress. This is because the soil of drip-irrigated rice is aerobic, and soil water content is close to the soil water field capacity. As a semi-aquatic plant, this water regime may not be sufficient for rice growth. Therefore, the objective of this hydroponic experiment was to determine the water potential that induces drought stress in rice.
A hydroponic experiment was performed to simulate different soil water conditions. Different PEG6000 was added to water to generate different water potentials; the response of rice will be similar when grown in water solutions and in soil under the same water conditions. This study focused on the relative growth rate (RGR) (1) and relative water content (RWC) (2), photosynthesis response (3), enzyme activity (4), and permeate and peroxidation products (5), and aimed to analyze the activity optimized water condition of drip-irrigated rice.

\section{MATERIAL AND METHODS}

\section{Materials and experimental setup}

The hydroponic experiment was conducted from April to June 2016 at the Key Lab of Oasis Ecology Agriculture of Xinjiang Production and Construction Group, Shihezi City, Xinjiang Province, China. Rice seeds (O. sativa L 'T-43') were surface-sterilized in $10 \% \mathrm{H}_{2} \mathrm{O}_{2}$ for $10 \mathrm{~min}$ and $70 \%$ ethanol for $5 \mathrm{~min}$, and then thoroughly rinsed in distilled water. Tianye Agriculture Research Institute (Tianye Group Ltd.) note that this rice cultivar performs well under drip irrigation. The seeds were soaked in distilled water in an incubator for $24 \mathrm{~h}$ at $37^{\circ} \mathrm{C}$ and then sown in vermiculite. After 15 days, the seedlings were transferred to a stainless-steel net stretched over $7 \mathrm{~L}$ plastic pots $(36 \mathrm{~cm}$ long $\times 28 \mathrm{~cm}$ wide $\times 10 \mathrm{~cm}$ high) containing Hoagland's nutrient solution (HOAGLAND; ARNON, 1950). The pots were then placed in a growth chamber with a $10 / 14 \mathrm{~h}$ light/dark photoperiod, $28 / 20^{\circ} \mathrm{C}$ day/night temperature, and $60-70 \%$ relative humidity. The plants were grouped to include 16 "hills" in each plastic pot, and three seedlings per hill (Figure 1). The nutrient solution was continuously aerated with an electric pump. The nutrient solution was changed every 7 days until the plants reached the internode elongation stage ( 80 days).

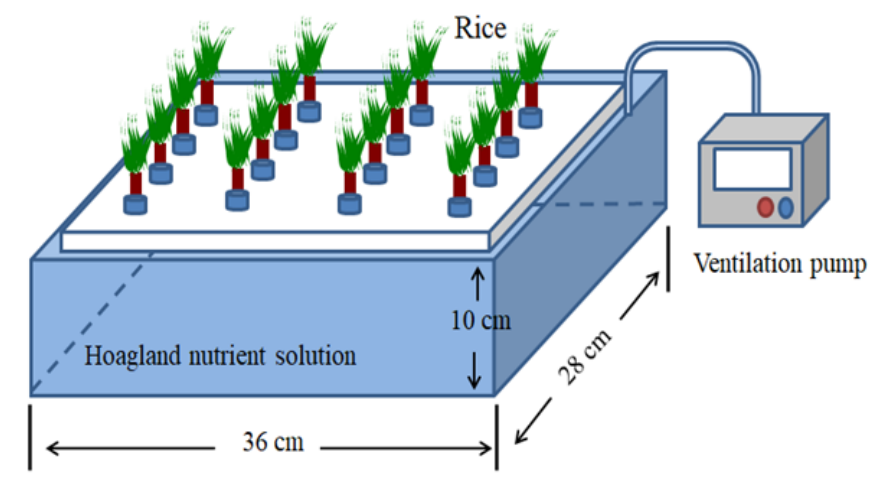

Figure 1. Schematic diagram of the hydroponic experiment. 
The osmotic potential of Hoagland's solution was adjusted with polyethylene glycol (PEG-6000, Jiangsu Hai'an Petrochemical Co., Ltd.) (FERREIRA et al., 2017). PEG-6000 was added to the solution at concentrations of $0,2.5,5.0$, and $7.5 \%$ (w/w) (referred to as CK, PEG2.5, PEG5.0, and PEG7.5, respectively). The osmotic potentials were $0.00,-0.02,-0.05$, and $-0.09 \mathrm{MPa}$ according to the Michel formula (MICHEL; KAUFMANN, 1973), respectively. Sixty-day-old rice seedlings were transplanted to the nutrient solution for 20 days. The nutrient solutions were changed every 3 days. The $\mathrm{pH}$ of the solution was adjusted daily to $\mathrm{pH}$ 5.8-6.5. Distilled water was added daily to replenish water lost through evaporation and transpiration.

\section{Measurements and analyses}

\section{RGR and RWC}

Leaf samples were collected 10 and 20 days after PEG treatment. The plant samples were weighed and then gently rinsed with deionized water. The plants from five hills were dried in an oven at $75^{\circ} \mathrm{C}$, and then the shoots were weighed with an electronic balance. The RWC of leaves was measured using the following formula (BARR; WEATHERLEY, 1962).

$$
R W C=\frac{\text { Fresh weight-Dry weight }}{\text { The relative turgidity weight }- \text { Dry weight }}
$$

Photosynthetic characteristics

Photosynthetic characteristics (i.e., net photosynthetic rate, stomatal conductance, intercellular $\mathrm{CO}_{2}$ concentration, and transpiration rate) of the youngest fully expanded leaves were measured with a LI-6400XT system (LI-6400, LiCor, Inc., Lincoln, NE, USA). The 6400-02B LED light source provided a photosynthetic photon flux density of $1,200 \mu \mathrm{mol} \mathrm{m} \mathrm{m}^{-2} \mathrm{~s}^{-1}$. The conditions were as follows: $25^{\circ} \mathrm{C}$ leaf temperature, $70 \%$ relative humidity, and $380 \pm 10 \mathrm{mmolCO}_{2} \mathrm{~m}^{-2} \mathrm{~s}^{-1}$.

Soluble protein content

The soluble protein content was determined according to the method described by Diezel, Kopperschlager and Hofmann (1972). Leaf samples $(0.5 \mathrm{~g})$ were ground with $5 \mathrm{~mL}$ phosphate buffer, centrifuged $3000 \mathrm{r} / \mathrm{min}$ for $20 \mathrm{~min}$ at $4^{\circ} \mathrm{C}$, and the supernatant was collected to obtain crude extracts of soluble protein. A $0.1 \mathrm{~mL}$ aliquot of the supernatant and $0.9 \mathrm{~mL}$ of distilled water were added to a plug test tube, followed by $5 \mathrm{~mL}$ Coomassie brilliant blue -CBBG-250 solution, After $2 \mathrm{~min}$, the absorbance was determined at $595 \mathrm{~nm}$, and a standard curve was used to calculate the protein content.

Antioxidant enzyme activities
Antioxidant enzymes were extracted as described by Zhou et al. (2005) with slight modification. Leaf samples $(0.5 \mathrm{~g})$ were frozen in liquid $\mathrm{N}$ and then finely ground with a chilled mortar and pestle. The samples were then added to $10 \mathrm{~mL}$ phosphate buffer ( $\mathrm{pH} 7.0)$ and centrifuged at 15,000 $\times g$ for $15 \mathrm{~min}$ at $4^{\circ} \mathrm{C}$. This supernatant corresponds to the enzyme extract in the following steps.

Superoxide dismutase (SOD; EC 1. 15. 1.1) activity was determined according to the method of Giannopolitis and Ries (1977). The reaction solution (3 mL) contained $13 \mu \mathrm{M}$ methionine, $63 \mu \mathrm{M} \rho$-nitro blue tetrazolium chloride (NBT), $1.3 \mu \mathrm{M}$ riboflavin, $50 \mathrm{mM}$ phosphate buffer ( $\mathrm{pH}$ 7.8), and enzyme extract. The reaction solution was incubated at $25^{\circ} \mathrm{C}$ for $10 \mathrm{~min}$ under fluorescent light at $80 \mu \mathrm{mol}$ photons $\mathrm{m}^{-2} \mathrm{~s}^{-1}$. Light absorbance was determined at $560 \mathrm{~nm}$ with a spectrophotometer (Model UV-2010, Hitachi, Japan). One unit of SOD activity was defined as the amount of enzyme required for $50 \%$ inhibition of the photochemical reduction of NBT.

Peroxidase (POD; EC 1.11.1.7) activity was determined according to the method of Kraus and Fletcher (1994). The reaction solution $(3 \mathrm{~mL})$ contained $50 \mathrm{mM}$ phosphate buffer $(\mathrm{pH} 7.0), 5 \mathrm{mM}$ guaiacol, $30 \mathrm{mM} \mathrm{H}_{2} \mathrm{O}_{2}$, and $0.1 \mathrm{~mL}$ enzyme extract. POD activity was calculated by measuring the increase in absorbance of oxidized tetraguaiacol polymer (extinction coefficient $26.6 \mathrm{mM}^{-1} \mathrm{~cm}^{-1}$ ) within $1 \mathrm{~min}$ at $470 \mathrm{~nm}$.

Catalase (CAT; EC 1. 11. 1.6) activity was assayed after dialysis following the method of Beers and Sizer (1953). The reaction mixture $(1.5 \mathrm{~mL})$ contained $1,000 \mu \mathrm{L} 100 \mathrm{mM} \mathrm{K}$-phosphate buffer $(\mathrm{pH}$ 7.0), $400 \mu \mathrm{L} 200 \mathrm{mM} \mathrm{H}_{2} \mathrm{O}_{2}$, and $100 \mu \mathrm{L}$ enzyme extract. $\mathrm{H}_{2} \mathrm{O}_{2}$ decomposition was determined by measuring the decrease in absorbance at $240 \mathrm{~nm}$ (extinction coefficient of $0.036 \mathrm{mM}^{-1} \mathrm{~cm}^{-1}$ ) using a UV-VIS spectrophotometer (Perkin Elmer, LAMBDA EZ 201, USA). Enzyme-specific activity was expressed as $\mu \mathrm{mol} \mathrm{H}_{2} \mathrm{O}_{2}$ oxidized $\mathrm{mg}^{-1}$ protein $\min ^{-1}$.

Malondialdehyde (MDA)and free proline content

MDA content was measured according to the method of Heath and Packer (1968). A $0.25 \mathrm{~g}$ leaf sample was homogenized in $5 \mathrm{~mL} 0.1 \%$ TCA. The homogenate was centrifuged at $10,000 \mathrm{~g}$ for $5 \mathrm{~min}$. A $1 \mathrm{~mL}$ aliquot of the supernatant was mixed with 4 $\mathrm{mL} 20 \%$ TCA containing $0.5 \%$ TBA. The mixture was heated at $95^{\circ} \mathrm{C}$ for $30 \mathrm{~min}$ and then quickly cooled in an ice-bath. After centrifuging at 10,000 g for $10 \mathrm{~min}$, the absorbance of the supernatant was read at $532 \mathrm{~nm}$. The value obtained for non-specific absorption at $600 \mathrm{~nm}$ was subtracted. The concentration of MDA was calculated using the extinction coefficient of $155 \mathrm{mM}^{-1} \mathrm{~cm}^{-1}$.

Free proline concentrations were determined using a modification of the method described by 
Bates, Waldren and Teare (1973). A leaf sample $(0.2$ g) was placed into $5 \mathrm{~mL}$ of aqueous sulfosalicylic acid (3\%) and kept in a boiling water bath for 30 min. The mixture was cooled to $25^{\circ} \mathrm{C}$. A $2.0 \mathrm{~mL}$ aliquot of the supernatant extract was mixed with 2.0 $\mathrm{mL}$ ninhydrin and $2 \mathrm{~mL}$ acetic acid. The mixture was maintained for $30 \mathrm{~min}$ in a boiling water bath and then cooled in an ice bath. Next, $5 \mathrm{~mL}$ of toluene was added, and the mixture was placed in the dark for $5 \mathrm{~h}$. Absorbance of the colored product was then read at $520 \mathrm{~nm}$.

\section{Statistical analysis}

Statistical analysis was performed with SPSS 17.0 analytical software. Quantitative factor should not be compared with mean test. The correct statistical procedure in this case was regression analysis to establish a relationship or mathematical function between the doses (quantitative factor: 0 $2.5-5.0-7.5 \%)$ and the variables.

\section{RESULTS AND DISCUSSION}

\section{Relative growth rate of rice}

The relative growth rate (RGR) of rice was significantly influenced by water potential and treatment duration (Figure 2). In general, the RGR of rice decreased as water potential decreased. Compared with the $\mathrm{CK}$ treatment, the RGRs were decreased by 23 and $13 \%$ following the PEG7.5 treatment for 10 and 20 days, respectively.

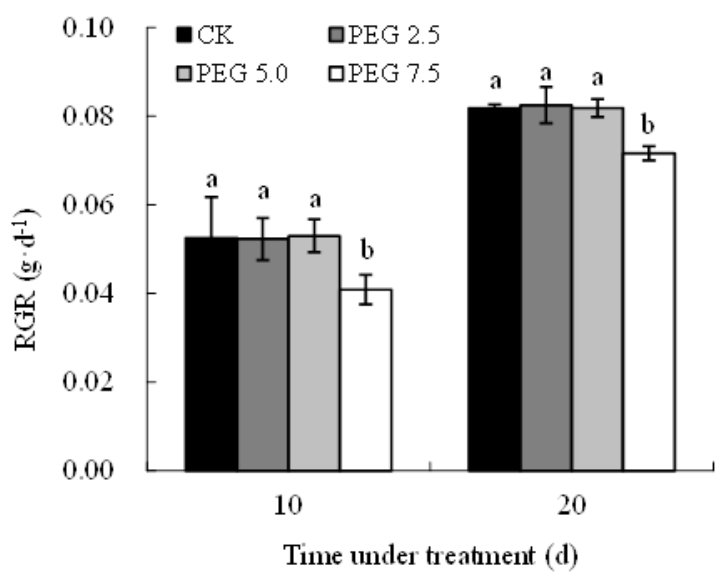

Figure 2. The relative growth rate (RGR) of rice water potential of the Hoagland's solution.

\section{Relative water content of rice}

Water potential significantly affected the RWC of rice (Figure 3). PEG7.5 treatment reduced RWC by $2.4 \%$ after 10 days and by $6.2 \%$ after 20 days compared with CK. The differences in RWC among the CK, PEG2.5, and PEG5.0 treatments were not significant at 10 days. However, PEG5.0 significantly reduced leaf water content compared with CK after 20 days.

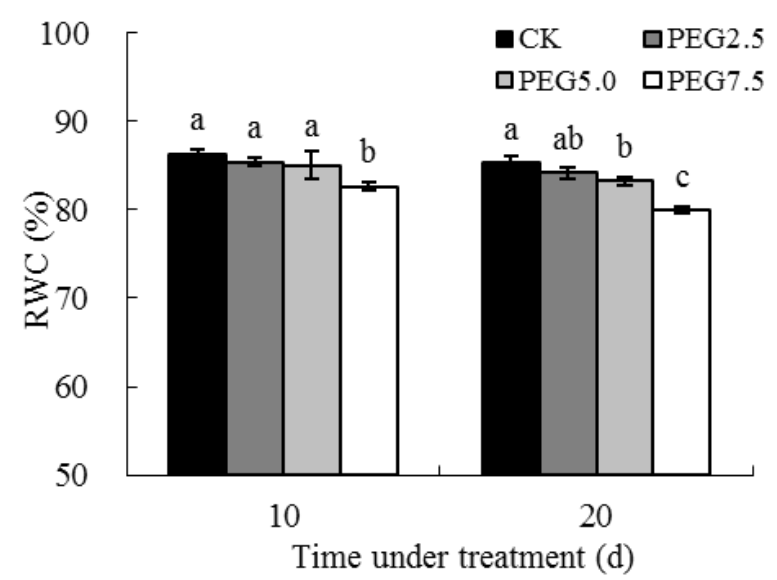

Figure 3. The relative water content (RWC) of rice water potential of the Hoagland's solution. 


\section{Photosynthetic characteristics of rice}

Water potential (W) and time (T) had significant interaction effects on $\mathrm{Pn}, \mathrm{Gs}$, and $\mathrm{Ci}$. Drought stress also had significant effects on $\mathrm{Tr}$; however, the water potential and time interaction were not significant (Table 1).

Net photosynthesis $(\mathrm{Pn})$ generally declined in the order PEG2.5, CK > PEG5.0 > PEG7.5 (Table 1). The differences between PEG2.5 and CK were not significant on either sampling date. Averaged across both sampling dates, PEG5.0 and PEG7.5 reduced net photosynthesis (Pn) by 35.5 and $47.3 \%$, respectively, compared with $\mathrm{CK}$. The differences between PEG5.0 and PEG7.5 were significant after 10 and 20 days.

Table 1. Photosynthetic characteristics of rice water potential of the Hoagland's nutrient solution.

\begin{tabular}{|c|c|c|c|c|c|}
\hline $\begin{array}{l}\text { Treatment } \\
\text { time (days) }\end{array}$ & $\begin{array}{l}\text { Water } \\
\text { stress }\end{array}$ & $\begin{array}{c}\mathrm{Pn} \\
\left(\mu \mathrm{mol} \cdot \mathrm{m}^{-2} \cdot \mathrm{s}^{-1}\right)\end{array}$ & $\begin{array}{c}\text { Gs } \\
\left(\mathrm{mol} \mathrm{H} \mathrm{H}_{2} \mathrm{O} \cdot \mathrm{m}^{-2} \cdot \mathrm{s}^{-1}\right)\end{array}$ & $\begin{array}{c}\mathrm{Ci} \\
\left(\mu \mathrm{mol} \cdot \mathrm{mol}^{-1}\right) \\
\end{array}$ & $\begin{array}{c}\operatorname{Tr} \\
\left(\mathrm{mmol} \cdot \mathrm{m}^{-2} \cdot \mathrm{s}^{-1}\right) \\
\end{array}$ \\
\hline \multirow[t]{4}{*}{10} & CK & $19.1 \mathrm{a}$ & $0.34 \mathrm{a}$ & $372.4 \mathrm{a}$ & $9.52 \mathrm{a}$ \\
\hline & PEG2.5 & $19.7 \mathrm{a}$ & $0.32 \mathrm{a}$ & $368.2 \mathrm{a}$ & $8.05 \mathrm{~b}$ \\
\hline & PEG5.0 & $16.3 \mathrm{~b}$ & $0.27 \mathrm{~b}$ & $342.1 \mathrm{~b}$ & $6.80 \mathrm{c}$ \\
\hline & PEG7.5 & $13.8 \mathrm{c}$ & $0.14 \mathrm{c}$ & $242.9 \mathrm{c}$ & $5.94 \mathrm{~d}$ \\
\hline \multirow[t]{4}{*}{20} & CK & $18.2 \mathrm{a}$ & $0.32 \mathrm{a}$ & $349.3 \mathrm{a}$ & $7.90 \mathrm{a}$ \\
\hline & PEG2.5 & $18.6 \mathrm{a}$ & $0.21 \mathrm{~b}$ & $319.8 \mathrm{~b}$ & $7.70 \mathrm{a}$ \\
\hline & PEG5.0 & $7.8 \mathrm{~b}$ & $0.15 \mathrm{c}$ & $226.8 \mathrm{c}$ & $5.81 \mathrm{~b}$ \\
\hline & PEG7.5 & $5.8 \mathrm{c}$ & $0.14 \mathrm{c}$ & $219.1 \mathrm{c}$ & $5.48 \mathrm{c}$ \\
\hline \multicolumn{6}{|c|}{ Two-way ANOVA (F value) } \\
\hline $\mathrm{T}$ & & $235.9 * *$ & $19.7 * *$ & $21.3 * *$ & $11.0 * *$ \\
\hline W & & $236.7 * *$ & $33.0 * *$ & $17.2 * *$ & $28.8 * *$ \\
\hline $\mathrm{T}^{*} \mathrm{~W}$ & & $48.3 * *$ & $6.0 * *$ & $3.8 *$ & $1.3 \mathrm{~ns}$ \\
\hline \multicolumn{6}{|c|}{ Means of main effects } \\
\hline $\mathrm{CK}$ & & $18.6 \mathrm{a}$ & $0.33 \mathrm{a}$ & $360.9 \mathrm{a}$ & $8.7 \mathrm{a}$ \\
\hline PEG2.5 & & $19.2 \mathrm{a}$ & $0.26 \mathrm{~b}$ & $344.0 \mathrm{a}$ & $7.8 \mathrm{~b}$ \\
\hline PEG5.0 & & $12.0 \mathrm{~b}$ & $0.21 \mathrm{c}$ & $284.5 b$ & $6.3 \mathrm{c}$ \\
\hline PEG7.5 & & $9.8 \mathrm{c}$ & $0.15 \mathrm{~d}$ & $236.8 \mathrm{c}$ & $5.7 \mathrm{c}$ \\
\hline
\end{tabular}

Within a column and within a water treatment, means with different letters are significantly different at $\mathrm{p}<0.05$. *and**, significant at the 0.05 and 0.01 levels (two-tailed), respectively. Pn: photosynthetic rate; Gs: stomatal conductance; $\mathrm{Ci}$ : intercellular $\mathrm{CO}_{2}$ concentration; Tr: transpiration rate

Stomatal conductance (Gs) generally declined in the order CK > PEG2.5 > PEG5.0 > PEG7.5. The differences between $\mathrm{CK}$ and PEG2.5 were not significant after 10 days but were significant after 20 days. The differences between PEG5.0 and PEG7.5 were significant after 10 days but not after 20 days. Averaged across both sampling dates, PEG2.5, PEG5.0, and PEG7.5 reduced Gs by 21.2, 36.4, and $54.5 \%$, respectively, compared with CK.

Intracellular $\mathrm{CO}_{2}$ concentrations $(\mathrm{Ci})$ exhibited trends similar to those observed for stomatal conductance (Gs). The differences between $\mathrm{CK}$ and PEG2.5 were only significant after 20 days, whereas the differences between PEG5.0 and PEG7.5 were only significant after 10 days. Averaged across both sampling dates, PEG2.5, PEG5.0, and PEG7.5 reduced intracellular $\mathrm{CO}_{2}$ by $4.7,21.2$, and $34.4 \%$, respectively, compared with CK.

Transpiration (Tr) generally declined in the order $\mathrm{CK}>$ PEG2.5 > PEG5.0 > PEG7.5. The differences between $\mathrm{CK}$ and PEG2.5 were not significant after 10 days. Averaged across both sampling dates and compared with CK, PEG2.5, PEG5.0, and PEG7.5 reduced transpiration by 10.3 , 27.6 , and $34.5 \%$, respectively.

Soluble protein content and antioxidant enzyme

\section{ctivities of rice}

Water status significantly affected leaf soluble protein concentrations on both sampling dates (Figure 4a). Leaf protein concentrations decreased in the order PEG7.5, PEG5.0 > PEG2.5 > CK after 10 days. The soluble protein concentration was $18.1 \%$ greater in PEG7.5 than in CK. This pattern changed after 20 days. Specifically, PEG2.5 and PEG5.0 significantly increased soluble protein by $12.6-14.6 \%$, whereas PEG 7.5 reduced soluble protein by $8.0 \%$. The activity of soluble protein was affected by PEG7.5 after 20 days.

The highest antioxidant activity was observed with PEG5.0, although the differences among treatments were not always significant (Figure 4b, c, d). Leaf SOD activities were 18.8-28.7\%, greater with PEG5.0 than with CK (Figure 4b). The PEG2.5 and PEG7.5 treatments presented significantly greater (8.1 and $6.8 \%$, respectively) SOD activity than CK after 10 days. However, after 20 days, there was no significant difference in SOD activity between PEG7.5 and CK. Leaf POD activity was significantly greater $(5.6 \%)$ with PEG5.0 than with CK after 10 days (Figure 4c). After 20 days, there was no significant difference in POD activity with CK, PEG2.5, and PEG5.0. Treatment with PEG7.5 resulted in the lowest POD activity among all 
treatments on both sampling dates (although it was not significantly less than with $\mathrm{CK}$ after 10 days). Leaf CAT activity with PEG5.0 after 10 and 20 days was 4.4 and $13.9 \%$ greater than with CK, respectively (Figure 4d). CAT activity with PEG2.5
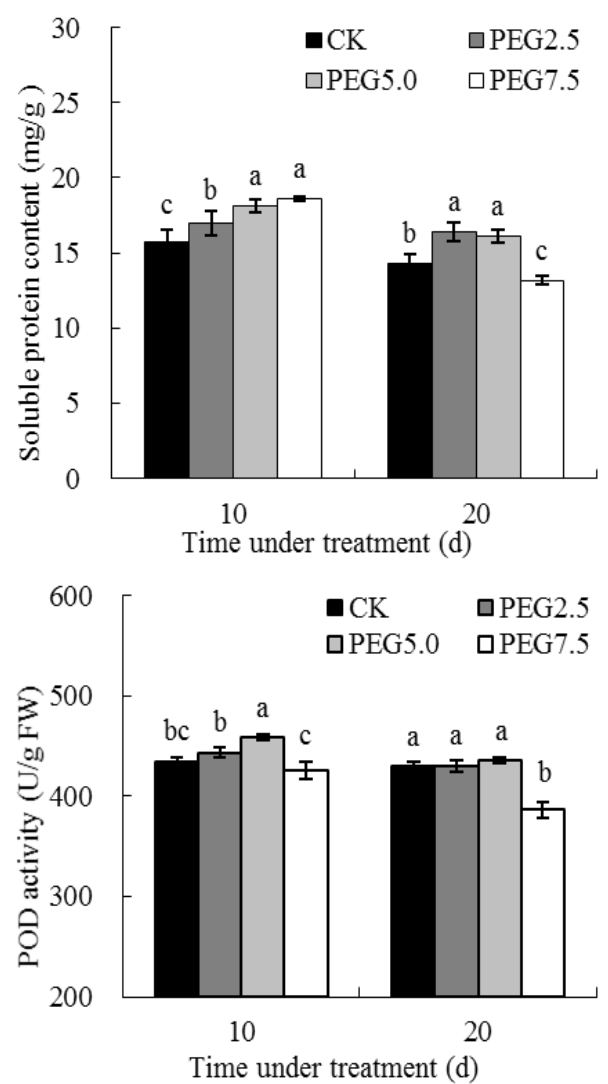

treatment was generally intermediate between that of PEG5.0 and CK, whereas PEG7.5 presented the lowest CAT activity (although this not significantly different than that with CK). POD and CAT activities were affected by high levels of PEG.

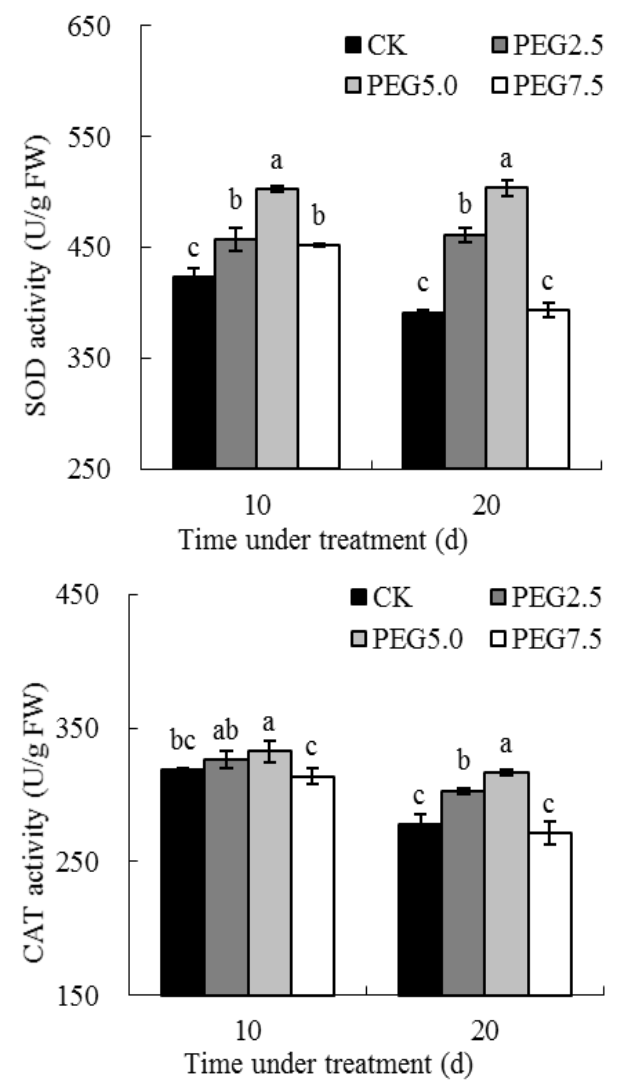

Figure 4. The soluble protein content, superoxide dismutase (SOD) activity, peroxidase (POD) activity, and catalase (CAT) activity of rice water potential of the Hoagland's solution.

\section{Malondialdehyde content of rice}

PEG7.5 treatment significantly increased leaf MDA concentrations, whereas PEG2.5 and PEG5.0 treatments had no significant effect on MDA concentration (Figure 5). Treatment with PEG2.5 and PEG5.0 reduced the MDA content by different degrees compared with the control treatment; however, the difference was not significant. Leaf MDA concentrations with PEG7.5 after 10 and 20 days were 18.8 and $43.8 \%$ greater than those with CK, respectively.

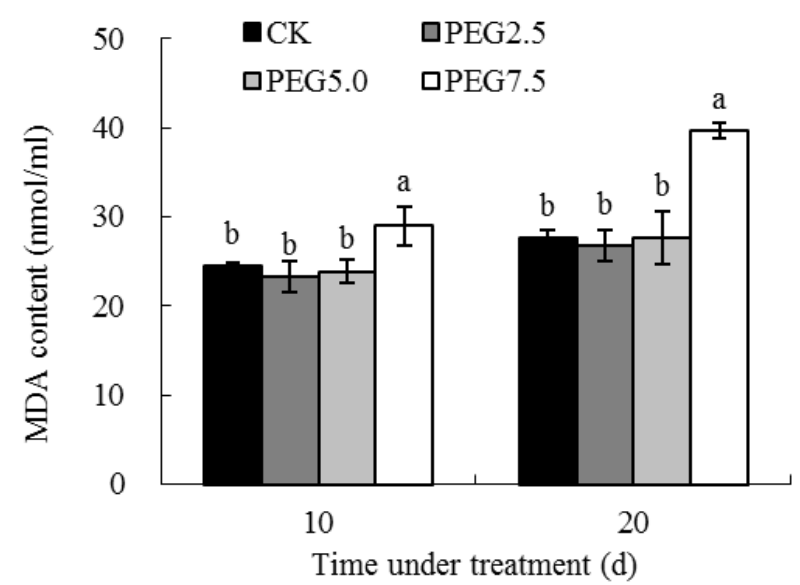

Figure 5. The malondialdehyde (MDA) concentrations of rice water potential of the Hoagland's solution. 


\section{Free proline in rice}

All PEG treatments significantly increased leaf proline concentrations (Figure 6). In general, free proline in rice increased as water potential decreased. The highest proline concentrations were observed with PEG5.0. After 10 days, leaf proline concentrations with PEG2.5, PEG5.0, and PEG7.5 were $30.2,107$, and $105 \%$ greater than that with $\mathrm{CK}$, respectively. After 20 days, leaf proline concentrations with PEG2.5, PEG5.0, and PEG7.5 were $68.3,122$, and $76.2 \%$ greater than with $\mathrm{CK}$, respectively.

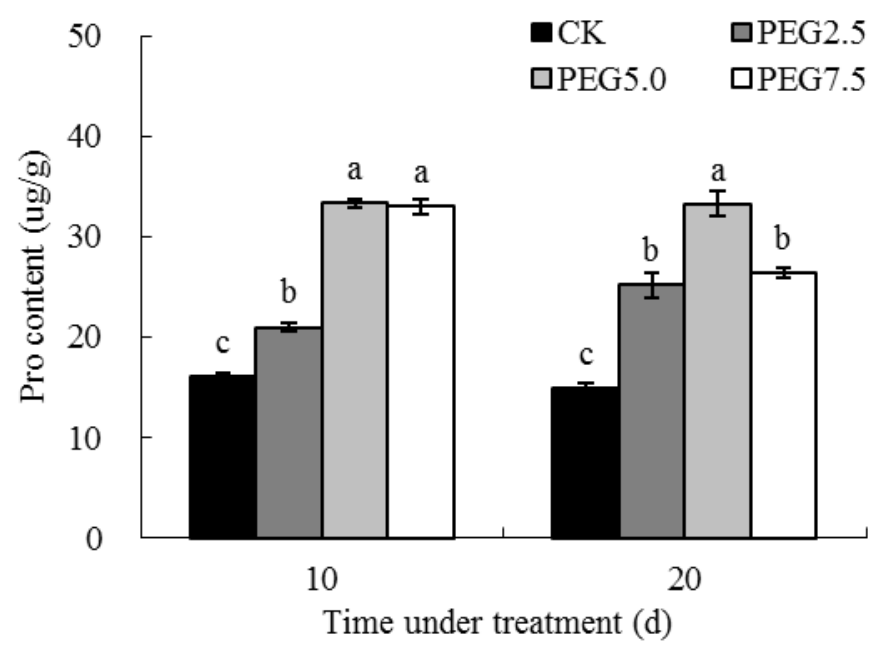

Figure 6. Free proline content of rice water potential of the Hoagland's solution. Error bars represent the standard error $(\mathrm{SE} ; \mathrm{n}=3)$.

The response of plants to drought stress is complex, and involves changes in morphology, physiology, and metabolism (SIKUKU et al., 2010). Reduced plant growth is the most typical symptom of drought stress. The present results showed that differences in water potential affected photosynthesis to a greater extent than any other variable in this study. There was no significant difference in the RGR and RWC between PEG 2.5 and PEG5.0 treatments after 10 and 20 days, respectively (Figure 2 ). Water potential greater than $-0.02 \mathrm{MPa}$ had no significant effect on the stomatal conductance and intercellular $\mathrm{CO}_{2}$ concentration in rice. This is consistent with previous findings reported by Chaves et al. (2002). PEG2.5 and PEG5.0 treatments had no significant effect on the RGR of rice; however, both treatments reduced transpiration compared with $\mathrm{CK}$ (Table 1). This suggests that water potentials between -0.02 and $-0.05 \mathrm{MPa}$ can reduce rice water demand without a significant effect on growth, as observed for RGR, which was only affected with PEG7.5 solution (Figure 2)

Drought stress leads to the accumulation of reactive oxygen species (ROS), generated mostly in chloroplasts, and to some extent, in mitochondria, resulting in oxidative stress. Plants under drought stress display some defense mechanisms, which protect them from the damaging effects of oxidative stress (CEYLAN; TURKAN; SEKMEN, 2013). These results indicate that a water potential of -0.02 and $-0.05 \mathrm{MPa}$ (107.2-91.1\% of field capacity) resulted in enhanced activities of SOD, POD, and
CAT in rice (i.e., PEG2.5 and PEG5.0, compared with $\mathrm{CK}$ ). This may accelerate the removal of ROS. A dynamic balance of active oxygen production and elimination in plants maintains active oxygen metabolism and protects membrane structure (MISHRA; BHOOMIKA; DUBEY, 2013). Proline concentrations were increased by water potentials greater than or equal to $-0.02 \mathrm{MPa}$ (i.e., Figure 6, PEG2.5, PEG5.0, and PEG7.5, compared with CK). The MDA concentrations were not affected by water potentials between -0.02 and $-0.05 \mathrm{MPa}$ (i.e., Figure 5, PEG2.5 and PEG5.0 compared with CK). Therefore, water-saving rice cultivation, such as drip -irrigation, results in physiological drought stress; however. mild drought stress $(<-0.05 \mathrm{MPa})$ did not inhibit shoot growth. This explains why dripirrigated rice exhibited high water efficiency and high yield. Although rice is a semi-aquatic plant, mild water stress (i.e., CK and PEG2.5, water potential between 0 and $-0.05 \mathrm{MPa}$ ) can maintain its growth rate, photosynthetic rate, and rice RGR.

Severe drought can retard crop growth and cause metabolic disorders. Plant growth is inhibited by a series of stress-induced physiological effects (MISHRA; BHOOMIKA; DUBEY, 2013). This study indicated that water potential of $-0.09 \mathrm{MPa}$ (PEG7.5) severely inhibited rice growth (Figure 2) and reduced the photosynthetic characteristics (Table 1). Compared with the control treatment, PEG7.5 reduced the activity of protective enzymes after 20 days (Figure 4) and increased free proline concentrations after 10 days, (Figure 6). Studies have 
shown that a reduction in the synthesis and accumulation of free amino acids in plants under drought stress can cause free proline concentrations to increase 10-100-fold (LUM et al., 2014; BAI et al., 2017). These results were consistent with those previous findings. PEG7.5 treatment also significantly increased MDA concentrations compared with CK. Increases in MDA can inhibit the activity of protective enzymes (GUNES et al., 2007). This results in the accumulation of active oxygen, which is transformed into more active $\mathrm{OH}$ by the Haber-Weiss and Fenton reactions (PIGNATELLO et al., 2006 ). The protective enzyme system cannot completely eliminate active oxygen free radicals. These free radicals increase the oxidative capacity of membrane lipids, rupturing cell membranes, and resulting in the release of cell contents. Ekmekci; Tanyolac; Ayhan (2008) found that drought stress induced physiological and biochemical metabolic disorders in plants leading to reduced enzymatic activity and changes in the cell membrane. Overall, these results indicated that soil water potential of $0.09 \mathrm{MPa}$ ( $80 \%$ of field capacity) induces severe drought stress in rice.

In this study, rain was simulated through a soil water regime with a nutrient solution containing PEG6000, and the water potential in the four treatments was $0.00,-0.02,-0.05$, and $-0.09 \mathrm{MPa}$. Soil water potential at field capacity is $-0.03 \mathrm{Mpa}$ (LEE; PIELKE, 1992). Chen (CHENG, 2010) studied the relationship between soil water content and obtained the following mathematical model: $\mathrm{y}=$ $-4.444 \ln (x)+40.567$, where " $x$ " is soil water potential (centibars) and " $y$ " is soil water content $(\%)$. From this equation, soil water potential was determined to be $-0.03 \mathrm{MPa}$ at field capacity $(25.5 \%)$, soil water potential at $90 \%$ and $80 \%$ field capacity was -0.06 and $-0.10 \mathrm{MPa}$, respectively. Because drip-irrigated rice maintains soil water content at around $90 \%$ of field capacity, the water potential at this point is $-0.06 \mathrm{MPa}$; in our study, water potentials lower than $-0.05 \mathrm{MPa}$ negatively affected rice growth and physiological states, showing that rice suffer mild to moderate drought stress under this water condition.

\section{CONCLUSION}

Drip-irrigated rice often maintains soil water content at $90 \%$ of field capacity, the water potential at this point is $-0.06 \mathrm{MPa}$. Therefore, soil water content of approximately $90 \%$ of field water capacity generates an environment with mild water stress for rice; however, rice growth rate, photosynthetic rate, and rice $\mathrm{RGR}$ were maintained. Irrigation depths should be increased if high yields of rice are desired under drip irrigation.

\section{ACKNOWLEDGEMENTS}

This work was supported by the National High Technology Research and Development Program of China (2011AA100508), by the National Science Funds of China (31471947) and by the National Science Funds of China (31860587). We are thankful to Dr. William Gale for help with the English in this manuscript.

\section{REFERENCES}

BAI, R. X. et al. Effect of salinity and soil temperature on the growth and physiology of dripirrigated rice seedlings. Archives of Agronomy and Soil Science, v. 63, n. 4, p. 513-524, 2017.

BARRS, H. D.; WEATHERLEY, P. E. A reexamination of the relative turgidity technique for estimating water deficits in leaves. Australian Journal of Biological Sciences, v. 15, n. 3, p. 413 $428,1962$.

BATES, L. S.; WALDREN, R. P.; TEARE, I. D. Rapid Determination of Free Proline for WaterStress Studies. Plant and Soil, v. 39, n. 1, p. $205-$ $207,1973$.

BEERS, R. F.; SIZER, J. F. Catalase assay with special reference to manometric methods, Science, v. 117 , n. 3052 , p. $710-712,1953$

CEYLAN, H. A.; TURKAN, I.; SEKMEN, A. H Effect of Coronatine on Antioxidant Enzyme Response of Chickpea Roots to Combination of PEG -Induced Osmotic Stress and Heat Stress. Journal of Plant Growth Regulation, v. 32, n. 1, p. 72-82, 2013.

CHAVES, M. M. et al. How Plants Cope with Water Stress in the Field? Photosynthesis and Growth Annals of Botany, v. 89, n. 7, p. 907-916, 2002.

CHENG, Y.W. Study on characteristics of the water requirement and yield componentsin spring wheat under drip irrigation in Northern Xinjiang. 2010. 83 f. Dissertation (Masters of Agriculture: Crop Physiology and Ecological) - Shihezi University, China. 2010.

DIEZEL, W.; KOPPERSCHIAGER, G.; HOFMANN, E. An improved procedure for protein staining in polyacrylamide gels with a new type of Coomassie Brilliant Blue. Analytical Biochemistry, v. 48, n. 2 , p. $617-620,1972$. 
EKMEKCI, Y.; TANYOLAC, D.; AYHAN, B. Effects of cadmium on antioxidant enzyme and photosynthetic activities in leaves of two maize cultivars. Journal of Plant Physiology, v. 165, n. 6, p. $600-611,2008$.

GIANNOPOLITIS, C. N.; RIES, S. K. Superoxide Dismutases: I. Occurrence in Higher Plants. Plant Physiology, v. 59, n. 2, p. 309-314, 1977.

GUO, Q. R.; CHEN, L. Analysis of advantage and prospects for rice drip irrigation under plastic film cultivation development in China. Chinese rice, v. 18 , n. 5 , p. $36-39,2012$

GUNES, A. et al. O Salicylic acid induced changes on some physiological parameters symptomatic for oxidative stress and mineral nutrition in maize (Zea mays L.) grown under salinity. Journal of Plant Physiology, v. 164, n. 6, p. 728-736, 2007.

FERREIRA, A. C. et al. Estresse hídrico e salino na germinação de sementes de feijão-caupi (vigna unguiculata cv. Brs tumucumaque). Revista Caatinga, v. 30, n. 4, p. 1009-1016, 2017.

HOAGLAND, D. R.; ARNON, D. I. The waterculture method for growing plants without soil. Circular: California Agricultural Experiment Station Circular, University of California: Berkely, 1950. v. 347, chap. 2, p. 32

HEATH, R. L.; PACKER, L. Photoperoxidation in isolated chloroplasts: I. Kinetics and stoichiometry of fatty acid peroxidation. Archives of biochemistry and biophysics, v, 125, n. 1, p. 189-198, 1968.

HE, H. B. et al. Rice Photosynthetic Productivity and PSII Photochemistry under Nonflooded Irrigation. The Scientific World Journal, v. 10, n. 1, p. 1-15, 2014.

PIGNATELLO, J. J. et al. Advanced Oxidation Processes for Organic Contaminant Destruction Based on the Fenton Reaction and Related Chemistry. Critical Reviews in Environmental Science and Technology, v. 36, n. 1, p. 1-84, 2006.

KRAUS, T. E.; FLETCHER, R. A. Paclobutrazol Protects Wheat Seedlings from Heat and Paraquat Injury. Is Detoxification of Active Oxygen Involved?. Plant and Cell Physiology, v. 35, n. 1, p. 45-52, 1994.

LAMPAYAN, R. M. et al. Adoption and economics of alternate wetting and drying water management for irrigated lowland rice. Field Crops Research, v. 170, n. 1, p. 95-108, 2015.
LEE, T. J.; PIELKE, R. A. Estimating the soil surface specific humidity. Journal of Applied Meteorology, v. 31, n. 5, p. 480-484, 1992.

LUM, M. S. et al. Effect of drought stress on growth, proline and antioxidant enzyme activities of upland rice. Japs Journal of Animal \& Plant Sciences, v. 24, n. 5, p. 1487-1493, 2014.

MICHEL, B. E.; KAUMFMANN, M. R. The osmotic potential of polyethylene glycol 6000. Plant physiology, v. 51, n. 5, p. 914-916, 1973.

MISHRA, P.; BHOOMIKA, K.; DUBEY, R. S. Differential responses of antioxidative defense system to prolonged salinity stress in salt-tolerant and salt-sensitive Indica rice (Oryza sativa L.) seedlings. Protoplasma, v. 250, n. 1, p. 3-19, 2013.

NELSON, A.; WASSMANN, R.; SANDER, B.O. Climate-Determined Suitability of the Water Saving Technology" Alternate Wetting and Drying" in Rice Systems: A Scalable Methodology demonstrated for a Province in the Philippines. PloS one, v. 23, n. 10, p. $145-268,2015$.

SIKUKU, P. A. et al. Chlorophyll fluorescence, protein and chlorophyll content of three nerica rainfed rice varieties under varying irrigation regimes. ARPN Journal of Agricultural and Biological Science, v. 5, n. 1, p. 19-25, 2010.

WANG, J. et al. China's water-energy nexus: greenhouse-gas emissions from groundwater use for agriculture. Environmental Research Letters, v. 7, n. 1, p. 14035-14044, 2012.

ZHANG, X. J. et al. Effect of $\mathrm{HCO}_{3}{ }^{-}$on rice growth and iron uptake under flood irrigation and drip irrigation with plastic film mulch. Journal of Plant Nutrition and Soil Science, v. 178, n. 6, p. 944-952, 2015.

ZHOU, B. et al. Nitric oxide is involved in abscisic acid-induced antioxidant activities in Stylosanthes guianensis. Journal of Experimental Botany, v. 56, n. 422, p. 3223-3228, 2005.

ZHU, Q. C. et al. Nutrient availability in the rhizosphere of rice grown with plastic film mulch and drip irrigation. Journal of Soil Sience and Plant Nutrition, v. 13, n. 4, p. 943-953, 2013. 